\title{
On the issue of determining the main factors of gas hazard in coal mines of Ukraine
}

\author{
Mykhailo Filatiev ${ }^{1, *}$, Elvira Filatieva ${ }^{1}$, Aleksandr Oleinichenko ${ }^{1}$, Mihaela Toderas $^{2}$, and Olga Kuderinova ${ }^{3}$ \\ ${ }^{1}$ Volodymyr Dahl East Ukrainian National University, Severodonetsk, Ukraine \\ ${ }^{2}$ University of Petrosani, Faculty of Mines, Mining Engineering, Surveying and Constructions Department, 20 University Str., \\ Petrosani, 332006, Romania \\ ${ }^{3}$ Karaganda Technical University, Development of Mineral Deposits Department, 56 N. Nazarbayev Str., Karaganda, 100027, Republic \\ of Kazakhstan
}

\begin{abstract}
The main sources of methane emission are located in the undermined coal-bearing strata, which is not taken into account by the requirements of regulatory documents when determining the category hazard of coal mines. Gas emission from each undermined source is not equally dependent on the tons of coal mined. The relative gas emission changes during the cleaning work and cannot be a criterion for assessing the gas hazard of the entire mine. The volatility of the gas emission index per unit area of the underworked space, which was formed because of monthly movements of the working faces, was established. In essence, this indicator repeats the dependence of the relative gas content per ton of coal mined, since the area of the underworked space is functionally related to the amount of coal mined for a certain period. Without coal mining, the rate of movement of the working face is equal to zero, and gas emission from a unit area continues for several months. As a result, the considered indicators do not have their specific meaning and, due to their inconstancy, they cannot reliably reflect the gas hazard of mines.
\end{abstract}

\section{Introduction}

The regulatory framework for safe mining of gas-bearing coal seams was laid down in the 1960s. This concerns the establishment of hazard categories of mines [1] and predictions of gas emission during mining operations [2]. The development of the requirements of these documents was based on the assumption of a direct proportional relationship between the level of gas emission and the amount of coal produced. To some extent, this approach was justified by the fact that the main source of gas emission during the treatment was the underworked reservoir. The share of gas emission from the broken coal and the exposed surface of the working face, during that period of development of the Donbass coal deposits, was $60 \div 80 \%$ of the total gas balance of the mining area. Over the past several decades, mining operations have been forced to move to deeper levels. This caused a significant change in the gas balance of the working areas during the cleaning work. In modern mines when mining at a depth of $500 \div 1500 \mathrm{~m}$ the main gas release up to $90 \%$ and more comes from the coal-bearing strata undermined by the workings. The level of gas emission from these sources (adjacent seams and enclosing rocks), in addition to coal mining, is influenced by other factors. These, first of all, include the processes of displacement of underworked rocks during the cleaning work [3]. Over the past, not only the main sources of methane emission have changed in quality and quantity, but also the factors that determine its level and methods of safe mining of gas-bearing coal seams [4-8]. Such changes in the conditions of mining operations have practically not been adequately reflected in the regulatory framework $[1,2]$, the provisions of which have not been revised for many years. For example, the gas hazard is confined only to the level of coal production, and the degree of development of cleaning work within the excavation area and the wing of the coalfield is not considered. Unfortunately, accidents with serious consequences associated with the ignition of gasair mixtures and their explosions in coal mines recur periodically. This indicates the relevance of the works aimed at establishing the factors that determine safe development of gas-bearing coal seams.

\section{Purpose, idea and research methodology}

The aim of this subsection is to establish the main factors that determine methane emission throughout the entire period of mining areas exploitation. This makes it possible to determine the influence of the degree of cleaning works development on the associated processes of undermined coal-bearing strata displacement and gas emission. To develop proposals in terms of improving the forecast of gas emission and establishing the category hazard of mines.

The idea is that the level of methane emission and the total amount of gas emission from undermined sources depends both on the size of the extraction pillar and on the 
speed of moving the active face. Monitoring throughout the entire period of the mining operation allows to assess the change in gas emission during the cleaning operations (removal of the face from the open pit) at all characteristic stages of coal mining - reaching targets, stable operation and reducing the load before stopping the face.

The indicators of gas emission for a certain movement of the active faces for a fixed period of time, including the official monthly average data for establishing the category of mines by their gas hazard, are considered.

The well-known experimental data [4,5], obtained respectively in the conditions of the A.F. Zasyadko mine, and the Newspaper "Izvestia" mine, as well as monthly average data for establishing the category hazard of the "Sukhodolskaya-Vostochnaya" mine and the D.F. Melnikov mine over the past four to five years. Basic information about the objects of observation is summarized in Table 1. In all cases, the roof was controlled by the complete collapse of the rocks. Experimental data made it possible to establish the amount of gas emitted per time interval.

\section{Research results and discussion}

In all cases, in the initial period of the mining areas exploitation, as the working faces were removed from the split furnaces, an increase in the amount of emitted gas was observed (Fig. 1). The increase in methane emission during this period is due to an increase in the underworked space and the development of displacement processes of underworked rocks to the settlement of the main roof with the subsequent development of these processes. After the formation of a constant height of the zone of rock displacement with a rupture of their continuity, stabilization of gas emission occurs at a certain level. In most cases, before stopping the working face, its speed decreases.

As a rule, the minimum rates of the active faces' movement correspond to the initial and final periods of exploitation of extraction areas, which is due to the specific features of technological processes when mining coal seams with long faces. They are characterized by the need for grinding in mechanisms and identifying possible defects in equipment installation. For these reasons, sometime is required to ensure the planned performance of the extraction areas.

A decrease in the speed of moving the active faces before stopping them is determined by the transition period associated with the need to commission the next extraction pillar. For the organization of cleaning work in the newly commissioned face, additional material and human resources are required, as well as a certain period of time for reaching the planned indicators.

Table 1. Information about geological and mining-engineering conditions of extraction areas mining.

\begin{tabular}{|c|c|c|c|c|c|c|}
\hline Face, seam & \begin{tabular}{|c|} 
Seam \\
capacity, $m$, \\
$\mathrm{m}$
\end{tabular} & \begin{tabular}{|c} 
Face \\
length, $L_{l}$, \\
$\mathrm{m}$ \\
\end{tabular} & $\begin{array}{l}\text { Length of underworked } \\
\text { extraction pillar, } L_{\mathrm{cm}}, \mathrm{m}\end{array}$ & $\begin{array}{c}\text { Depth of } \\
\text { cleaning } \\
\text { works, } H, \mathrm{~m} \\
\end{array}$ & $\begin{array}{l}\text { Moving speed of } \\
\text { active faces, } v_{o \psi} \text {, } \\
\mathrm{m} / \mathrm{month}\end{array}$ & $\begin{array}{c}\text { The amount of gas released } \\
\text { within the extraction pillar, } \\
\text { million m }\end{array}$ \\
\hline \multicolumn{7}{|c|}{ A.F. Zasyadko mine [9] } \\
\hline $16^{\text {th }}$ eastern, $m_{3}$ & 2.10 & 270 & 1918 & 1195 & $18 \div 132$ & 57.2 \\
\hline \multicolumn{7}{|c|}{ Newspaper "Izvestia" mine [10] } \\
\hline 1st western, $\ell_{2}^{b}$ & 0.90 & $111 \div 185$ & 1422 & 300 & $9 \div 64$ & 4.7 \\
\hline 1st western, $\ell_{2}^{b}$ & 0.90 & $68 \div 100$ & 775 & 300 & $6 \div 63$ & 2.5 \\
\hline 2 th western, $\ell_{2}^{b}$ & 0.90 & 200 & 1186 & 300 & $27 \div 139$ & 13.6 \\
\hline $\begin{array}{c}\text { 2th bis western, } \\
\ell_{2}^{B}\end{array}$ & 0.90 & 185 & 279 & 300 & $9 \div 41$ & 4.7 \\
\hline 3 th western, $\ell_{2}^{b}$ & 0.90 & 215 & 1559 & 300 & $31 \div 144$ & 16.7 \\
\hline 4th western, $\ell_{2}^{b}$ & 0.90 & 210 & 1491 & 300 & $52 \div 153$ & 15.5 \\
\hline 5th western, $\ell_{2}^{b}$ & 0.90 & 216 & 1421 & 300 & $56 \div 149$ & $22.0^{*}$ \\
\hline 6th western, $\ell_{2}^{B}$ & 0.90 & 230 & 1169 & 300 & $25 \div 95$ & $23.0 *$ \\
\hline 7 th western, $\ell_{2}^{b}$ & 0.90 & 230 & 1309 & 300 & $21 \div 118$ & 16.4 \\
\hline 8 th western, $\ell_{2}^{b}$ & 0.90 & 215 & 787 & 300 & $0 \div 131$ & 12.8 \\
\hline $\begin{array}{c}\text { 9th western, } \\
\ell_{2}^{b} \ell_{2}^{b} \\
\end{array}$ & 0.90 & 250 & 329 & 300 & $0 \div 73$ & 4.4 \\
\hline \multicolumn{7}{|c|}{ 'Sukhodolskaya - Vostochnaya' mine } \\
\hline 24th eastern, $i_{3}^{\prime}$ & 2.20 & 240 & 1112 & 1016 & $5 \div 70$ & 50.5 \\
\hline 25 th western, $i_{3}^{\prime}$ & 2.20 & 265 & 700 & 1198 & $15 \div 47$ & 26.0 \\
\hline $\begin{array}{c}\text { 12th bis eastern, } \\
i_{3}^{\prime}\end{array}$ & 2.20 & 240 & 879 & 965 & $12 \div 36$ & 34.8 \\
\hline 34th eastern, $i_{3}^{\prime}$ & 1.20 & 180 & 813 & 948 & $22 \div 53$ & 11.6 \\
\hline 37 th western, $i_{3}^{\prime}$ & 1.20 & 180 & 1316 & 911 & $18 \div 88$ & 10.1 \\
\hline \multicolumn{7}{|c|}{ D.F. Melnikov mine } \\
\hline 1-я northern, $\ell_{6}$ & 1.30 & 220 & 1210 & 853 & $0 \div 58$ & 11.4 \\
\hline
\end{tabular}

* - in total with the amount of gas emitted from outside the extraction areas during the activation of rock movement 


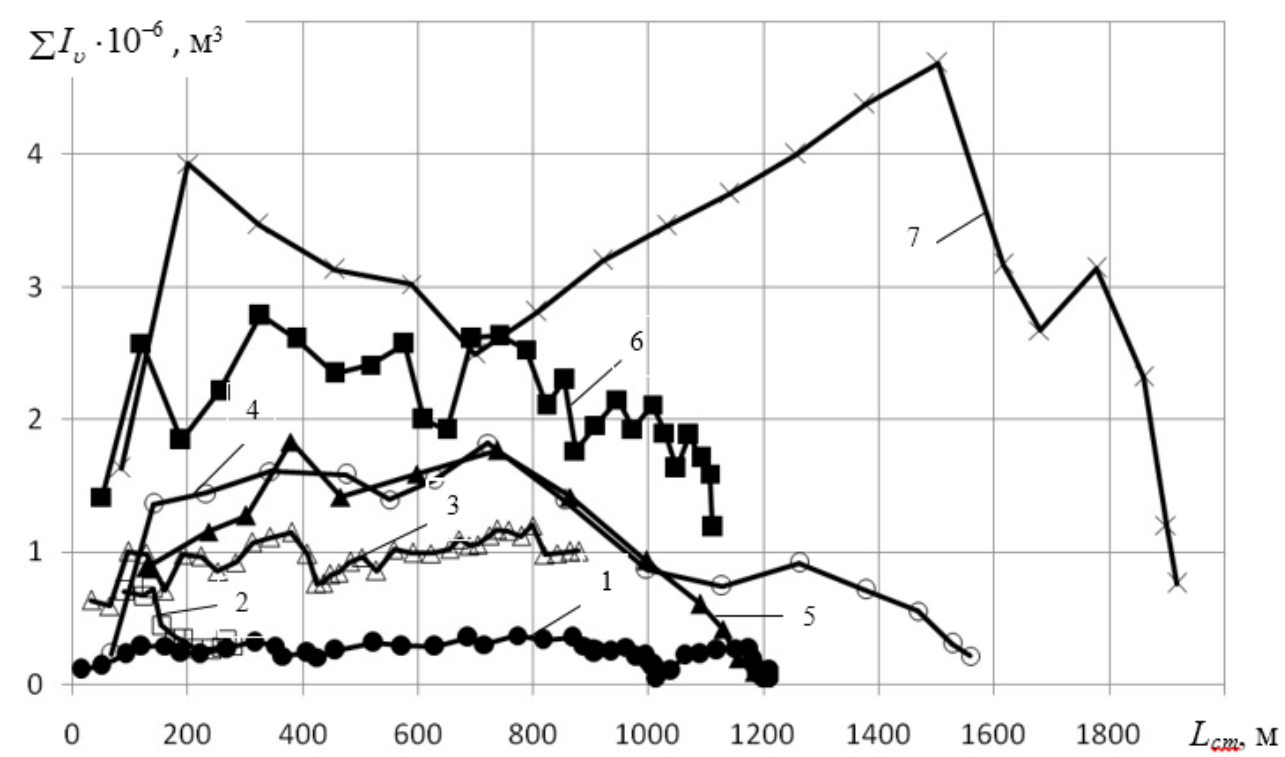

Fig. 1. Change in average monthly volumes of gas emission $\left(\sum I_{v}\right)$ depending on the removal of active faces $(L)$ from cut workings. 1, 2, 3, 4, 5, 6, 7 - graphs of changes in gas emission, respectively, for the D.F. Melnikov mine (1st northern face layer $\ell_{6}$ ), the Newspaper "Izvestia" mine (2nd bis, 2nd and 3rd western faces of the seam $\ell_{2}^{k}$ ), "Sukhodolskaya-Vostochnaya" (12th bis and 24th eastern facfes of the seam $i_{3}^{\prime}$ ), the A.F. Zasyadko mine (16th eastern seam $\left.m_{3} m_{3}\right)$; $\bullet, \square, \mathbf{\square}, \circ, \boldsymbol{\Lambda}, \Delta, \times$ - experimental data.

Experimental data (Table 1, Fig. 1) shows that the volumes of the emitted gas depend on the dimensions of the extraction pillars. They are characterized by their length $\left(L_{c m}\right)$ and the length of the exploited longwalls $\left(L_{\pi}\right)$, as well as by the speed of active faces. This can be seen in the example of the Newspaper "Izvestia" mine faces. In the section of the 2 nd bis of the western face (curve 2) with a pillar length of $279 \mathrm{~m}$. and the speed of moving the active face $9 \div 41 \mathrm{~m} /$ month. much less gas was emitted in comparison with the 2nd (curve 3 ) and 3rd (curve 4) western faces, for which the value of $L_{c m}$ was 1186 and $1559 \mathrm{~m}$, respectively, and $v_{о ч}-27 \div 139$ and $31 \div 144$ $\mathrm{m} / \mathrm{month}$.

The influence of the active faces movement rate on the values $\sum I_{v_{\text {очі }}}$ is also confirmed by experimental data for the 12th bis (curve 5) and 24th (curve 6) eastern faces of the "Sukhodolskaya-Vostochnaya" mine. With the same length of faces $(240 \mathrm{~m})$ in the section of the 24th eastern face and $v_{\text {оч }}=5 \div 70 \mathrm{~m} / \mathrm{month}, 50.5$ million $\mathrm{m}^{3}$ of gas was emitted (Table 1), and in the section of the 12 th bis eastern face at $v_{o y}=12-36 \mathrm{~m}^{3} /$ month only 34.8 million $\mathrm{m}^{3}$ of methane was emitted.

The above facts indicate that gas emission is associated both with the size of the area of the underworked face space $\left(S_{c m}=L_{\Omega} \times L_{c m}\right)$, and with the speed of the active faces movement $\left(v_{\text {оч }}\right)$. In addition to the specified technological parameters $\left(S_{c m}, v_{\text {оч }}\right)$, other factors also affect gas emission from the undermined strata. First of all, they should include the reserves (resources) of methane, which is in the coal-rock strata before the cleaning works. Preliminarily, the estimated gas reserves can be judged by the gas content of the coal in the developed seams. Natural gas content of seam $m_{3}$ (the A.F. Zasyadko mine) is $35 \mathrm{~m}^{3} /$ t.m.a.m., seam $\mathrm{i}_{3}^{\prime}$ (the "Sukhodolskaya-Vostochnaya" mine) - $33 \mathrm{~m}^{3} /$ t.m.a.m. When underworking the $\ell_{2}^{\mathrm{B}}$ seam, the Newspaper "Izvestia" mine, its natural gas content decreased from 35 to $3 \div 8 \mathrm{~m}^{3} /$ t.m.a.m. as the pillars were underworked along the uprising and the active faces approached the zone of gas weathering and geological disturbance (Karlovsky discharge). The natural gas content of the $\ell_{6}$ seam (the D.F. Melnikov mine) did not exceed $8 \mathrm{~m}^{3} /$ t.m.a.m. This ratio of natural gas content of the underworked seams obviously influenced the amount of gas emitted from the undermined coal-rock strata (Table 1, Fig. 1). The question of the possible volumes and forms of gas occurrence in the coal-bearing strata requires a separate detailed study.

The influence of the active faces movement rate $\left(v_{\text {оч }}\right)$ on the amount of gas emitted from the undermined strata $\left(\mathrm{I}_{v}\right)$ manifested itself in the form of differing dependencies for different objects (Fig. 2, a). During the development of the $m_{3}$ seam, a directly proportional dependence was observed (straight line 2), and during the extraction of the $i_{3}$ and $\ell_{6}$ seams, an exponential dependence (curves 1 and 3 , respectively).

When underworking the $\ell_{2}^{\mathrm{B}}$ seam, the trend of dependence $I_{v}=f\left(v_{o u}\right)$ also approaches exponential (Fig. 2, b). Large deviations of the experimental data from the averaging curve are caused by significant differences in gas resources in the undermined massif during the development of individual pillars due to the influence of geological disturbances, different degrees of cleaning works in the wing of the mine field, and the presence of gas emission outside some extraction areas under the influence of the activation of rock displacement.

In the presence of additional sources outside the extraction areas, ventilation schemes were used, which contributed to an additional flow of gas into the area workings. The given results of mine observations indicate that in order to ensure the safe development of gas-bearing coal seams, along with technological factors $\left(L_{c m}, L_{l}, S_{v}^{\prime}\right.$, $v_{\text {ou }}$ ) and natural gas resources in the undermined strata, it is necessary when designing ventilation schemes for 
extraction areas to provide for the exclusion of gas from external sources under the influence of general mine depression.

a)

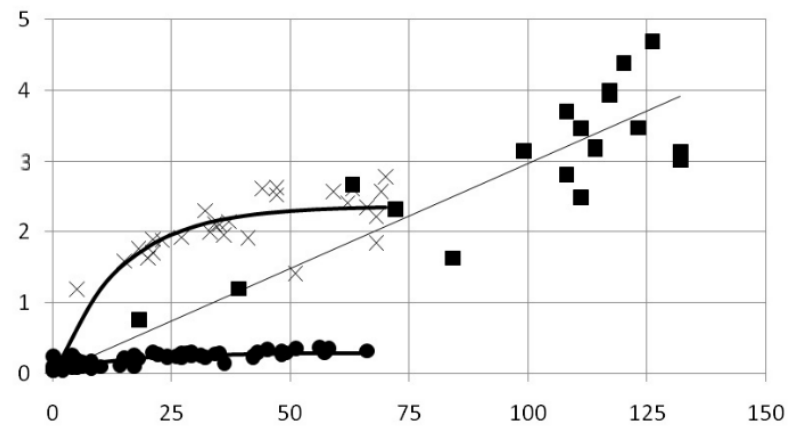

b)

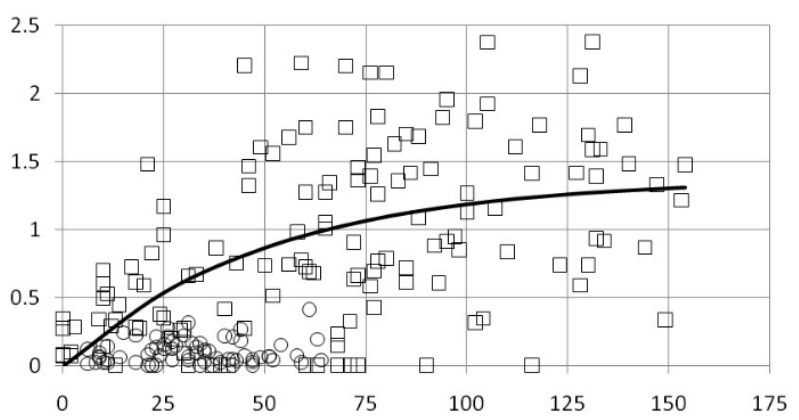

Fig. 2. Dependence of the released amount of gas $\left(\mathrm{I}_{v}\right)$ from the undermined coal-rock strata on the active faces movement rate $\left(v_{\text {оч }}\right)$ under conditions of different mines. 1, 2, 3, 4 - averaging lines, respectively, for the experimental data of the "Sukhodolskaya-Vostochnaya" mine (24th eastern face, seam $\mathrm{i}_{3}^{\prime}$ ), the A.F. Zasyadko mine (16th eastern face, seam $\mathrm{T}_{3}$ [9]), the D.F. Melnikov mine (1st northern face, layer $\ell_{6}$ ), the Newspaper "Izvestia" mine (2nd bis and 2-9th western faces, seam $\ell_{2}^{b}[10]$ ); $\times, \square, \bullet, \square-$ experimental data for averaging lines; 0 experimental data for the 1 st and 1 st bis of the western faces of the Newspaper "Izvestia" mine located directly in the zone of geological disturbance; $R, r$ - correlation ratio and correlation coefficient, respectively.

Of scientific and practical interest is the dependence of gas emission per unit area of undermined space $\left(\frac{\mathrm{I}_{v}}{S_{v}^{\prime}}\right)$ on the active faces movement rate $\left(v_{o u}\right)$. The $\frac{\mathrm{I}_{v}}{s_{v}^{\prime}}$ indicator is insufficiently studied to date. The graphs of such dependencies (Fig. 3) show the variability of this parameter for each object of observation. In essence, the $\frac{I_{v}}{S_{v}^{\prime}}=f\left(v_{\mathrm{O}}\right)$ dependence repeats the dependence of the relative gas abundance per ton of coal mined, since the area $\left(S_{v}^{\prime}\right)$ for each mining area is functionally related to the amount of coal mined for a certain period of time. In the absence of coal mining $\left(v_{\mathrm{O}}=0\right)$, gas emission per unit area of the worked-out area does not have its specific meaning, since the value of this parameter tends to infinity. This is due to the presence of gas emission from underworked sources for a long time (several months) when the active face is stopped $\left(v_{04}=0\right)$. The above circumstances do not allow the $\frac{I_{v}}{S_{v}^{\prime}}$ indicator to be used as a criterion for gas hazard in the course of cleaning work.

For practical purposes, the most suitable parameter for assessing the gas hazard may be the gas e4mission indicator $\sum I_{c m}^{i}$, which characterizes the total amount of gas emitted from the undermined sources from the start of operation of the extraction area to the current moment.

The main advantage of the $\sum I_{\mathrm{cT}}^{i}$ indicator is its functional dependence for specific extraction areas. The $\sum I_{\mathrm{cT}}^{i}$ parameter unambiguously increases as the working faces $(L)$ move away from the split working (Fig. 4, a). In a similar way, the $\sum I_{c m}^{i}$ indicator depends on the area of the underworked space (Fig. 4, b).

The given graphs indicate that under unchanged geological and mining-engineering conditions, the total amount of emitted gas changes in direct proportion as the length of the underworked pillar increases (Fig. 4, a) or the area of the underworked space (Fig. 4, b). This dependence was unambiguously characteristic of the extraction areas of the D.F. Melnikov mine (line 1) and the A.F. Zasyadko mine (line 3), where mining and geological conditions did not change as the mining pillars were worked out. In the conditions of the mine. The Newspaper "Izvestia" mine found a deviation of experimental data (curve 2) from a directly proportional relationship (line 2 '), which is caused by a decrease in gas reserves in the underworked strata as the active faces move away from cut workings and approach the zone of gas weathering or geological disturbance. Despite the changes in the mining and geological conditions of the working areas during the development of the $\ell_{2}^{b}$ seam, a close correlation was established $(r=0.97)$ of the amount of emitted gas on the area of the underworked space of individual working areas (Fig. 5).

As the active faces of the 12 th bis and 24th eastern faces moved away from the split furnaces ("Sukhodolskaya-Vostochnaya" mine), the experimental data $\sum \mathrm{I}_{v}^{\mathrm{i}}$ (curve 4 ) deviated from the directly proportional relationship upward (Fig. 4, line 4). This indicates a change in mining and geological conditions and an increase in the amount of gas per unit of undermined area. Knowing the $\sum \mathrm{I}_{v}^{i}$ change, when removing stope from cut workings $(L)$ or an increasing area of undermined space $\left(S^{\prime}{ }_{v}^{i}\right)$, it is not difficult to reliably predict gas emission for any stage of development of the next extraction pillars. The obtained results of experimental data processing indicate that for specific geological and miningengineering conditions, a reliable indicator of gas hazard can be the ratio of the total amount of emitted gas, referred to the area of the extraction pillar being underworked at the current time or the end of the cleaning work in the extraction pillar. The change in the $\frac{\sum I_{v}^{i}}{\sum S^{\prime}{ }_{v}^{i}}$ indicator in the initial period of the excavation areas operations is associated with the removal of the active faces from the cut workings $(L)$ and the development of the processes of displacement of the undermined rocks with subsequent precipitation of the main roof. With sufficient removal of the active face $(L)$, stabilization occurs, if the geological and mining-engineering conditions of the excavation areas exploitation do not change (Fig. 6). This type of change $\frac{\sum I_{v}^{i}}{\sum s_{v}^{i}}$ was observed for the faces of the D.F. Melnikov (curve 1) and the A.F. Zasyadko mines (curve $6)$.

In the conditions of the Newspaper "Izvestia" mine, 
this kind of dependence was established for the extraction pillars of the 3rd (curve 3 ) and 2nd (curve 4) western faces (Fig. 6). The length of these extraction pillars was, respectively, 1559 and $1186 \mathrm{~m}$, which made it possible to stabilize the processes of rock displacement when the active faces were removed from the cut workings at a distance of more than $250 \div 350 \mathrm{~m}$, and together with them to reach approximately constant values for the indicator $\frac{\sum I_{v}^{i}}{\sum s_{v}^{i}}$

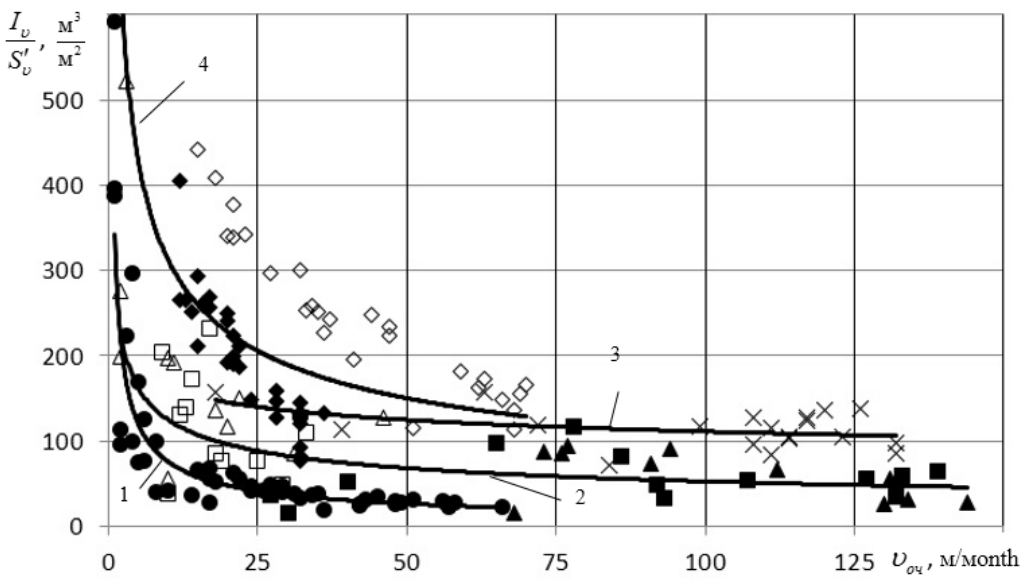

Fig. 3. The dependence of the specific gas emission in relation to the unit of area of the worked-out space $\left(\frac{I_{v}}{S_{v}^{\prime}}\right)$, corresponding to the monthly rate active faces movement $\left(v_{\text {оч }}\right)$. 1, 2, 3, 4 - averaging curves, respectively, for the D.F. Melnikov mine (1st northern face, seam $\ell_{6}$ ), the Newspaper "Izvestia" mine (2nd bis, 2nd, 3rd, 9th western faces, same $\ell_{2}^{\mathrm{B}}$ ), the A.F. Zasyadko mine (16th eastern face, seam $\mathrm{T}_{3}$ ), "Sukhodolskaya-Vostochnaya" (12th bis, 24th eastern face, seam $i_{3}^{\prime}$ ).
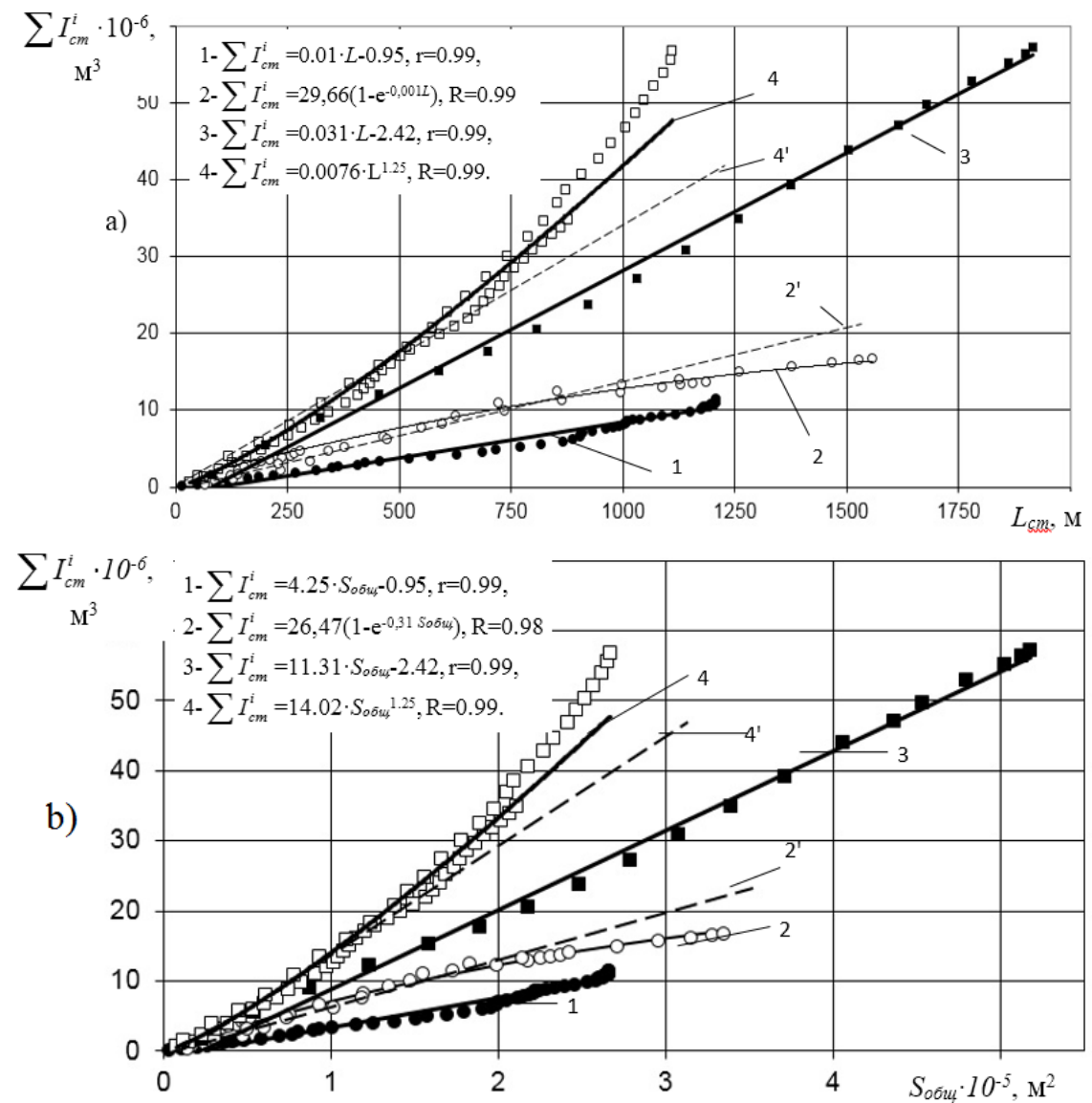

Fig. 4. Dependence of the total amount of gas emitted from the undermined coal-rock strata $\left(\sum I_{v}^{i}\right)$ as the active face (a) moves $(L)$ and the area $\left(S_{c m}\right)$ of the worked-out space (b) increases. 1, 2, 3, 4 - averaging lines, respectively, for the D.F. Melnikov mine (1st northern face, seam $\ell_{6}$ ), the Newspaper "Izvestia" mine (2nd bis, 2 nd, 3rd western faces, seam $\ell_{2}^{\mathrm{B}}$ ), the A.F. Zasyadko mine (16th eastern seam $\mathrm{T}_{3}$ ), and the "Sukhodolskaya-Vostochnaya" mine (12th bis, 24th eastern faces, seam i $\mathrm{i}_{3}^{\prime}$ ); 2', 4' - predicted direct $\sum I_{c m}$ dependencies for unchanged mining and geological conditions in comparison with the beginning of the exploitation of extraction areas, respectively, for the faces of the Newspaper "Izvestia" and "Sukhodolskaya-Vostochnaya" mines; •, ०, $\mathbf{\square}, \square-$ experimental data; r, R - correlation coefficient and correlation ratio, respectively. 


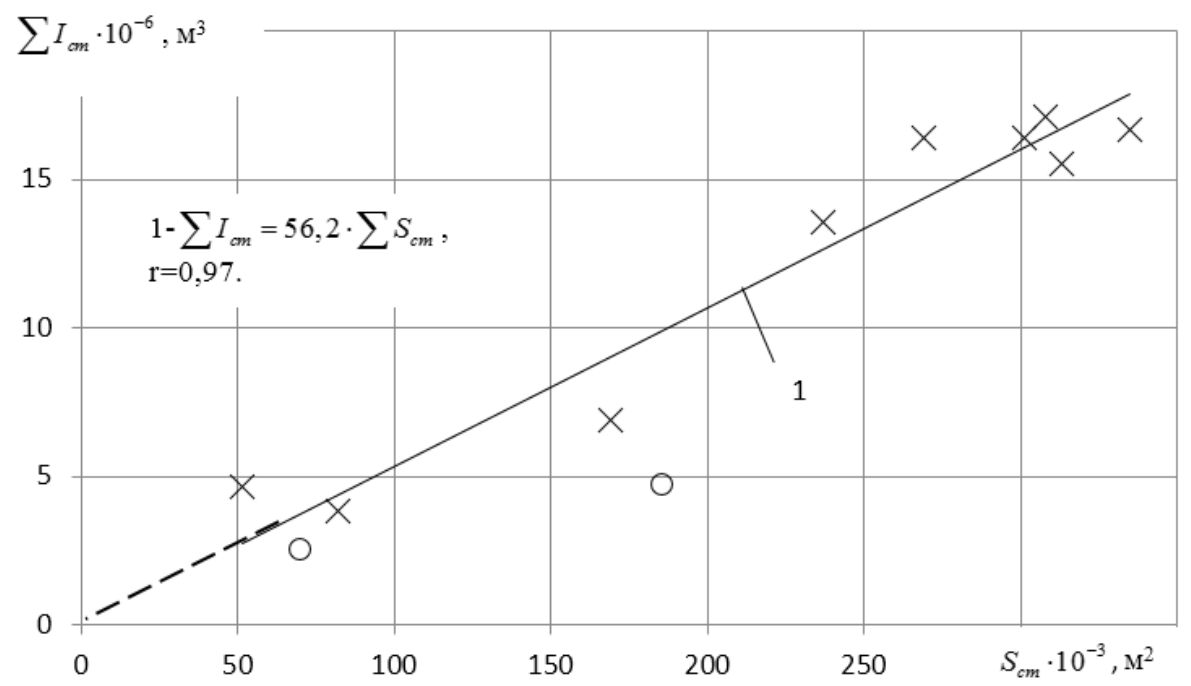

Fig. 5. Dependence of the amount of released gas $\left(\sum I_{c m}\right)$ within the excavation areas of the Newspaper "Izvestia" mine from the area of underworked spaces of stopped faces $\left(S_{c m}\right)$. 1- averaging line for faces located outside the immediate zone of geological disturbances; $\mathrm{r}$ - correlation coefficient; $\times$ - experimental data for faces $(2 \mathrm{nd}, 2 \mathrm{nd}$ bis, 3rd, 4th, 5th, 6th, 7th, 8th, 9th) outside the zone of direct influence of geological violations; $\bigcirc$ - experimental data for faces (1st and 1st bis) in the immediate zone of influence of geological disturbances.

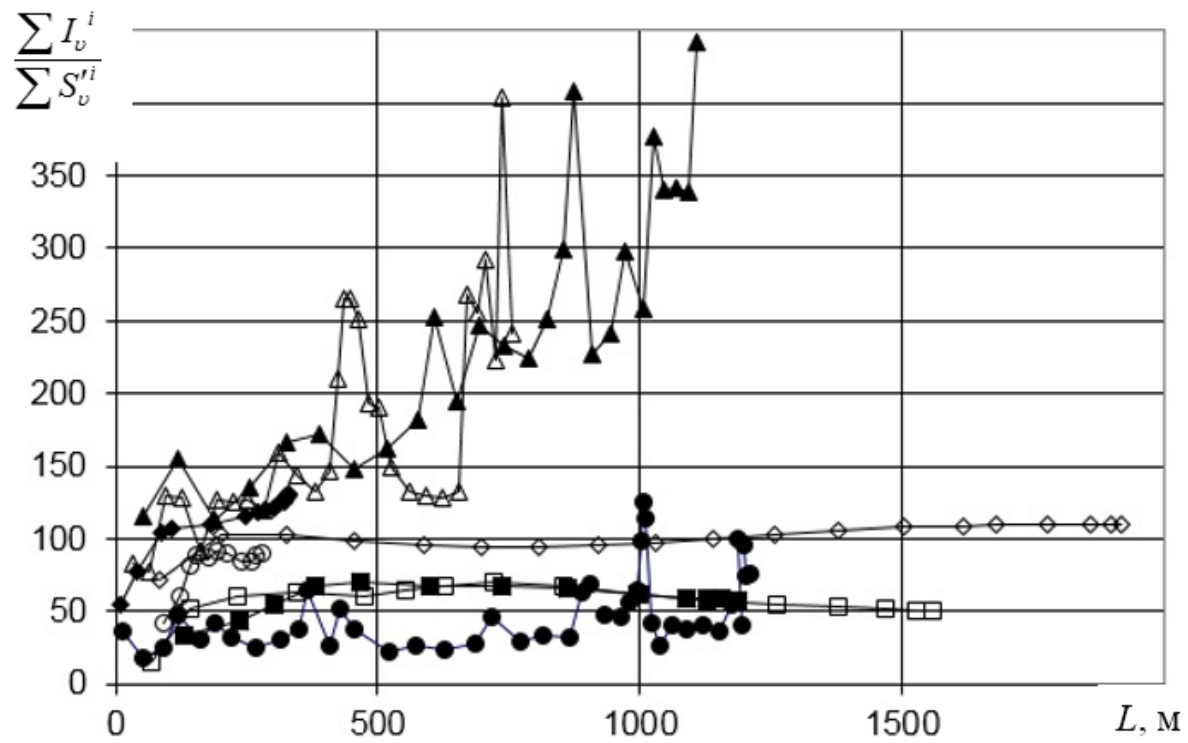

Fig. 6. Change in the specific gas emission relative to a unit area of the underworked space of the extraction pillars $\left(\frac{\sum I_{v}^{i}}{\sum S^{\prime}{ }_{v}^{i}}\right)$ when removing $(L)$ the active faces from the cut workings. 1,2,3,4,5,6,7,8 - curves of the $\frac{\sum I_{v}^{i}}{\sum S^{\prime}{ }_{v}^{i}}$ indicator change, respectively, in the conditions of the D.F. Melnikov mine (1st northern face, seam $\ell_{6}$ ), the Newspaper "Izvestia" mine (2nd bis, 2nd, 3rd, 9th western faces, seam $\ell_{2}^{\mathrm{B}}$ ), the A.F. Zasyadko mine (16th eastern face, seam $\mathrm{T}_{3}$ ), the "Sukhodolskaya-Vostochnaya" mine (24th, 12th bis eastern faces, seam $\left.i_{3}^{\prime}\right) ; \bullet, \circ, \mathbf{\square}, \square, \diamond, \diamond, \boldsymbol{\Delta}, \Delta$ - experimental data.

During the operation of the 2nd bis (curve 2) and 9th (curve 5) western faces, there was no opportunity for the development of rock displacement processes to such an extent, since the length of their extraction pillars was, respectively, only 279 and $329 \mathrm{~m}$. For this reason, during mining of faces with short pillars only showed an increase in $\frac{\sum I_{v}^{i}}{\sum S_{v}^{i}}$ values to a certain level without their further stabilization. It should be noted that the average advance velocity of the 2nd bis and 9th western faces for the entire period of their mining was insignificant and amounted to 0.7 and $0.9 \mathrm{~m} /$ day, respectively. In the mining areas of these faces, during the period of operation, 4.7 and 4.4 million $\mathrm{m}^{3}$ of methane were emitted into mine workings and degassing wells, respectively. At approximately the same rate of movement $\left(v_{\text {оч }}\right)$ and the amount of emitted gas $\left(\sum \mathrm{I}_{v}^{i}\right)$, the change in the $\frac{\sum I_{v}^{i}}{\sum{S^{\prime}}_{v}^{i}}$ parameter curves (Fig. 6, curves 5 and 2) as the working faces moved away from the cut workings significantly differed from each other. 
After stopping the faces, the $\frac{\sum I_{v}^{i}}{\sum{S^{\prime}}_{v}^{i}}$ indicator for these faces was respectively 90.4 and $53.9 \mathrm{~m}^{3} / \mathrm{m}^{2}$. This difference is explained by the distinctive features of face exploitation. The length of the $2 \mathrm{nd}$ bis of the western face was $185 \mathrm{~m}$, and the 9 th western face was $250 \mathrm{~m}$. With little differing average rates of moving faces $(0.7$ and $0.9 \mathrm{~m} /$ day $)$ and the length of the pillars (279 and $329 \mathrm{~m})$, the area the underworked spaces of the considered faces differed by more than 1.5 times (51.6 and 82.3 thousand $\mathrm{m}^{2}$ ). The natural gas content of the underworked seam during the operation of the 2 nd bis of the western face was 24.0 $\mathrm{M}^{3} /$ t.m.a.m., and during the development of the 9th western face $-35.0 \mathrm{~m}^{3} / \mathrm{t}$.m.a.m. This indicates that the gas resources in the undermined coal-bearing strata of the 9th western face should have been approximately one and a half times higher than the $\frac{I_{\mathrm{CT}}}{S_{\mathrm{CT}}^{\prime}}$ indicator for the 2 nd bis of the western face. If, in addition to the natural gas content of the developed reservoir, we also consider the area of the underworked pillars, then the total gas emission $\mathrm{I}_{\mathrm{CT}}$ in the 9th western section should have been 2.3 times higher than this indicator for the 2 nd bis of the western face. The experimental data did not confirm such a relation between $\mathrm{I}_{\mathrm{CT}}$ and $\frac{I_{\mathrm{CT}}}{S_{\mathrm{CT}}^{\prime}}$. The $\mathrm{I}_{\mathrm{CT}}$ indicator for both faces was approximately the same, and $\frac{I_{\mathrm{CT}}}{S_{\mathrm{CT}}^{\prime}}$ for the 2 nd bis of the western face it was almost 1.7 times higher than its value for the 9th western face. The obtained experimental data can only be explained by the sequence of mining of these faces. The extraction pillar of the 2 nd bis of the western face during its mining was isolated from all sides by a coal mass, and the extraction pillar of the 9th western face was adjacent to the underworked area of the previously mined ten faces. In the first case, gas was emitted only within the mining area, and in the second, due to the direction of the depression, it was carried out from the local workings to the general mine. In the conditions of the "Sukhodolskaya-Vostochnaya" mine when the active faces of the 24th (curve 7) and 12th bis (curve 8) eastern faces of the seam $i_{3}^{\prime}$ (Fig. 5) were removed from the cut workings, the change in the values of the $\frac{\sum I_{v}^{i}}{\sum s_{v}^{i}}$ indicator was approximately the same. This indicates that for these faces, geological and mining-engineering conditions change in approximately the same way during the development of cleaning works.

If the area of the underworked space $\left(S_{\mathrm{y}}^{\prime i}\right)$, which was formed during the monthly movement of the active face $\left(v_{\mathrm{o \Psi}}^{\mathrm{i}}\right)$, is less than the area of the underworked space $\sum S_{v}^{i}$, which determines the gas emission $\sum I_{v}^{i}$, then the $\frac{I_{v}^{i^{\prime}}{ }^{i}}{{ }_{v}}$ value will always be greater then $\frac{I_{v}^{i}}{\sum S^{\prime}{ }_{v}^{i}}$. The equality of these indicators is possible only for cases when the monthly rate of active faces movement ensures the extraction of the formation in an area corresponding to the size of the gas emission zone. The dimensions of the gas emission zone above the active face are determined by the zones of active movement of the undermined rocks. The projection of the size of such a zone behind the active face according to [3] is 0.466 of the depth $(H)$ of the cleaning work. For example, for the conditions of the Newspaper "Izvestia" mine, the gas emission zone behind the active face is about $140 \mathrm{~m}$, and for the conditions of the A.F. Zasyadko mine - about $550 \mathrm{~m}$. The maximum speed of active faces movement of about $140 \mathrm{~m} / \mathrm{month}$ was provided in some months only for several faces (2nd, 3rd, 4th, 5th western) of the Newspaper "Izvestia" mine. For these cases, the values of $\frac{I_{v}^{i^{\prime}}}{S}{ }_{v}^{i}$ and $\frac{I_{v}^{i}}{\sum s_{v}^{i}}$ in all cases were close to each other, which confirms the reliability of determining the size of active movement zones of underworked rocks and the corresponding dimensions of the underworked space, which determine gas emission from the coal-rock strata.

On the site of the 16th eastern face of the $m_{3}$ seam of the A.F. Zasyadko mine the reached speeds (132 $\mathrm{m} / \mathrm{month}$ ) of the active face (Table 1) were significantly less than the projection of the active movement zone of rocks behind the active face. This, obviously, predetermined higher $\frac{I_{S}^{i_{v}^{\prime}}}{S}$ values in all cases compared to $\frac{I_{v}^{i}}{\sum s_{v}^{i}}$ after removal of the active face from the cut working at a distance of more than $550 \mathrm{~m}$. Confirmation of the coincidence of the sizes of gas evolution zones with zones of active rock movement requires additional research.

\section{Conclusions}

Based on the generalization of the results of the studies carried out to establish the main factors of gas hazard in coal mines of Ukraine, the following conclusions have been drawn:

- the regulatory framework for safe mining of gasbearing coal seams is based on research carried out $50 \div 60$ years ago. Over the past, due to the transition to deeper layers, the gas balance and the sources of methane emission during the cleaning work have changed significantly. In modern mines, the main share of gas emission comes from the undermined coal-rock strata, and the requirements of regulatory framework for the establishment of gas hazard are focused on directly proportional dependence on the level of coal production from the underworked seam. The change in the gas balance and the share of the main sources of methane emission of its constituents led to a change in the factors that determine the danger of mining operations based on the gas factor. The provisions of the regulatory framework regarding the determination of the gas hazard and the forecast of gas emission have not been revised for several decades;

- the total amount of gas emitted from the undermined coal-rock strata, all other things being equal, directly depends on the area of the undermined space of the mined extraction pillars;

- the current level of gas emission depends both on the resources of methane in the undermined sources, and on the rate of the active face movement. The total amount of emitted methane remains constant for the specific dimensions of the mining field; 
- the indicator of the amount of gas emitted per unit area of the undermined space, formed in the process of a monthly movement of the active face, is not a constant parameter for specific mining and geological and mining conditions. This is due to the non-coincidence, in most cases, of the active faces movement speed for a certain period of time (a month) with the sizes of the gas emission zones from the undermining array after the passage of the active face. The change in this indicator is similar to the dependence of gas emission per ton of coal mined. For this reason, it cannot be a criterion for assessing the gas hazard in mines;

- with sufficient development of cleaning works in the mine field, additional sources of gas emission appear outside the exploited working area under the influence of the activation of the undermined rocks movement. This phenomenon must be taken into account when designing ventilation schemes for mining areas and the direction of action of a general mine depression.

The scientific results obtained make it possible to develop a new methodology for assessing the gas hazard in coal mines and predicting gas emission from the undermined coal-rock strata based on the existing production experience and technical documentation for establishing the hazard category of coal enterprises in previous years in accordance with the regulatory framework in force at that time.

\section{References}

1. NPAOP 10.01-1.01-10, Pravila bezpeki u vugil'nih shahtah (Kiev, 2010)

2. S. Yanko Rukovodstvo po proektirovaniyu ventilyacii ugol'nyh shaht (Osnova, Kiev, 1994)

3. M. Filatiev, E. Filatieva, A. Dubovik, Inzhenernaya geomekhanika pri otrabotke ugol'nyh plastov (Lisichansk, DonSTU, 2017)

4. A.T. Ajruni, Teoriya i praktika bor'by s rudnichnymi gazami na bol'shih glubinah (Nedra, Moscow, 1981)

5. V. Mihajlov, D. Kuz'min, N. Silaev, $O$ metanovydelenii za predelami vyemochnyh uchastkov iz "staryh" ranee otrabotannyh etazhej(gorizontov), Sb. MakNII. 8, 33-38 (1972)

6. V. Myaken'kij, Sdvizhenie $i$ degazaciya porod $i$ ugol'nyh plastov pri ochistnyh rabotah (IGTM, Kiev, 1975)

7. A.M. Morev, I.M. Evseev, Degazaciya sblizhennyh plastov (Nedra, Moscow, 1975)

8. A. Ajruni, I. Evseev, L. Zenovich, T. Mhatvari, Isskustvennoe uvelichenie zashchitnogo dejstviya pri razrabotke vybrosoopasnyh plastov (CNIEI, 7, 1984)

9. V.V. Bokij, O.I. Kasimov, Ugol' Ukrainy. 5, 17-21 (2005)

10. N.I. Antoshchenko et al., Bezopasnaya otrabotka gazonosnyh ugol'nyh plastov s uchetom geomekhanicheskih processov sdvizheniya podrabotannyh porod (Alchevsk, DonSTU, 2014) 